\title{
Pyruvate Carboxylase Deficiency: A Benign Variant with Normal Development
}

\author{
R. N. VAN COSTER, P. M. FERNHOFF, D. C. DE VIVO \\ Division of Pediatric Neurology, Columbia Presbyterian Medical Center, New York, New York 10032 [R.N.V.C., \\ D.C.D.V.J and Division of Medical Genetics, Department of Pediatrics, Emory University School of Medicine, \\ Atlanta, Georgia 30322 [P.M.F.]
}

\begin{abstract}
The devastating nature of a pyruvate carboxylase deficiency is underscored by the uniformly fatal outcome of the neonatal (French) type and the severely disabling and ultimately fatal outcome of the infantile (North American) type. We report a 7-y-old girl with metabolic and biochemical features of the North American phenotype. Remarkably, the clinical course has been benign with preservations of motor and mental abilities. The residual enzyme activity in cultured skin fibroblast homogenates was $1.8 \%$ and cross-reacting material was present in normal abundance and electrophoretic mobility. She has had several episodes of metabolic acidosis with elevated lactate, pyruvate, alanine, $\beta$-hydroxybutyrate, acetoacetate, lysine, and proline values, and undetectably low aspartate concentrations. These crises have been managed by rehydration and bicarbonate therapy. We are unable to provide a satisfactory explanation for the uniquely benign clinical course that has been experienced by this patient. (Pediatr Res 30: 1-4, 1991)
\end{abstract}

\section{Abbreviations}

CRM, cross-reacting material

MW, molecular weight

PC, pyruvate carboxylase

SSC, standard saline citrate

TBS, Tris-buffered saline

PC is a mitochondrial matrix enzyme that catalyzes the ATPdependent fixation of $\mathrm{CO}_{2}$ to pyruvate yielding oxaloacetate (13 ). This reaction is essential to the function of the Krebs cycle, gluconeogenesis (4), and lipogenesis $(5,6)$. The enzyme is expressed in brain, liver, kidney, adrenal gland, lactating mammary gland, fibroblasts, white blood cells, adipose, and other tissues $(5,7-9)$. Low activities are found in skeletal muscle. Tissuespecific isoenzymes are not known. The PC holoenzyme is a tetramer composed of four identical monomers $(\alpha 4)$ each with a MW of $125 \mathrm{kD}(10)$. Partial cDNA clones corresponding to the $3^{\prime}$ terminal of PC mRNA are available $(6,11)$, and the gene is located on the long arm of chromosome 11 (6).

Thirty-four patients with PC deficiency have been reported. Sixteen were severely ill in the neonatal period (French phenotype) with lactic acidosis, citrullinemia, hyperlysinemia, and

Received July 27, 1990; accepted February 21, 1991.

Correspondence and reprint requests: Darryl C. De Vivo, M.D., Neurological Institute, 710 West 168 Street, New York, NY 10032

Supported by a grant from the Colleen Giblin Charitable Foundation for Pediatric Neurological Research. R.N.V.C. was supported by grants from the National Foundation of Scientific Research of Belgium and from the Fulbright Foundation, Washington, DC. He currently is located at the University Hospital, Kinderkliniek "C. Hooft," De Pintelaan 185, 9000 Gent, Belgium. hyperammonemia (12-22). Essentially all these patients died within the first 4 mo of life. Eighteen patients had clinical symptoms with lactic acidosis during infancy (North American phenotype) $(7-9,18,23-31)$. These patients had severe mental and motor developmental delay and death during infancy or early childhood.

We have encountered a patient, now $6 \frac{1 / 2}{2}$ years of age, with severe PC deficiency documented in cultured skin fibroblasts who has had normal mental and motor development. To our knowledge, this child is the only patient with a "benign form" of PC deficiency.

\section{CASE REPORT}

This 7-y-old girl is the only child of a nonconsanguineous marriage. The full-term pregnancy, labor, and delivery were uncomplicated. Birth weight was $4500 \mathrm{~g}$. Growth and development during the first year of life were normal. At 7 mo of age, she was hospitalized briefly for vomiting and dehydration, and was hospitalized again at 14 mo for evaluation of a 1-d history of vomiting and rapid respirations. Physical examination at that time revealed an acutely ill infant. Body weight and length were above the 95 th percentile, and the head circumference was 48 $\mathrm{cm}$ (90-95th percentile). Although afebrile, her respiratory rate was $60 / \mathrm{min}$. Auscultatory and radiographic findings were consistent with bronchiolitis. Serum glucose was $14 \mathrm{mM}$, sodium $132 \mathrm{mM}$, chloride $111 \mathrm{mM}$, bicarbonate $1.5 \mathrm{mM}$, and urea nitrogen $4.1 \mathrm{mM}$. Blood gases were $1.7 \mathrm{kPa}(13 \mathrm{~mm} \mathrm{Hg}) \mathrm{PCO}_{2}$ and $17.3 \mathrm{kPa}(130 \mathrm{~mm} \mathrm{Hg}) \mathrm{PO}_{2}$. The $\mathrm{pH}$ was 6.89 and the base excess $-28.5 \mathrm{mM}$. Urinary $\mathrm{pH}$ was 5.0 ; large quantities of ketones were present. Treatment included oxygen, bronchodilators, sodium bicarbonate, and a single dose of intramuscular insulin. She responded quickly to treatment and was discharged on the 4th day of hospitalization. One wk later she was readmitted for a metabolic evaluation. Serum chemistry profile was normal, but the blood lactic acid value was $5.5 \mathrm{mM}$ (normal 0.5 to 2.2 ). Blood ammonia was normal. Plasma amino acid profile by anion exchange chromatography, however, revealed elevated alanine [852 $\mu \mathrm{M}$ (normal 99 to 313)], lysine [160 $\mu \mathrm{M}$ (normal 45 to 144)], and proline [281 $\mu \mathrm{M}$ (normal 51 to 185)]. Citrulline was normal and aspartate was undetectably low. The 24-h urine lactic acid content was $1.48 \mathrm{mg} / \mathrm{mg}$ creatinine (normal $<0.1$ ) as analyzed by gas chromatography/mass spectrometry.

The child was discharged but readmitted $7 \mathrm{~d}$ later with a 24-h history of decreased appetite, restlessness, and unsteady gait. On admission she was afebrile, tachypneic $(60 / \mathrm{min})$, tachycardic $(178 / \mathrm{min})$, and ataxic. Serum glucose was $8 \mathrm{mM}$, bicarbonate $4.9 \mathrm{mM}$, lactic acid $7.3 \mathrm{mM}$, and pyruvic acid $0.306 \mathrm{mM}$ (normal $<0.15$ ). She responded rapidly to i.v. fluids and bicarbonate, and was discharged after $2 \mathrm{~d}$ of hospitalization.

The child was hospitalized again at 16,25,31, and 47 mo of age for acute episodes of lactic acidosis. Each episode was preceded by a brief illness and decreased appetite and responded 
rapidly to i.v. fluids and bicarbonate therapy. Several milder episodes were treated at home with oral bicarbonate therapy and increased fluids. At 47 mo of age, the child weighed $24.5 \mathrm{~kg}$ ( $>95$ th percentile) and her neurologic development was normal except for a mild dysarthria. When last seen at $6^{1 / 2}$ y of age, the child was attending the first grade and performing all age-appropriate activities. She was doing well in school except for some difficulty with mathematics. She continued to be free of severe episodes of lactic acidosis, but was given supplemental oral fluids and bicarbonate whenever she was febrile. She was a large child whose height was $132 \mathrm{~cm}$ ( $>95$ th percentile) and who weighed $42 \mathrm{~kg}$ ( $>95 \mathrm{th}$ percentile). Except for macrosomia, obesity, and mild dysarthria, her physical and neurologic examinations were normal.

\section{MATERIALS AND METHODS}

Tissue culture supplies were purchased from Gibco Laboratories (Grand Island, NY). Laboratory reagents and chemicals were purchased from Sigma Chemical Company (St. Louis, MO), SDS-polyacrylamide electrophoresis reagents and the streptavidin-horseradish peroxidase conjugate from Bio-Rad (Rockville Center, NY), DNA polymerase and NADH from BoehringerMannheim Biochemicals (Indianapolis, IN), and ${ }^{32} \mathrm{P}$-nucleotides from New England Nuclear (Wilmington, DE).

Fibroblasts were cultured from biopsied skin specimens and trypsinized as described previously (32). The cell pellet was resuspended in nine volumes of homogenizing buffer $(0.25 \mathrm{M}$ sucrose, $10 \mathrm{mM}$ Tris- $\mathrm{HCl}, \mathrm{pH} 7.4$, and $2 \mathrm{mM}$ EDTA). The suspension was homogenized in a glass tube with a Teflon pestle for 10 passes at $300 \mathrm{rpm}$. Triton X-100 was added to a $0.01 \%$ homogenate, which was allowed to sit on ice for $30 \mathrm{~min}$ before assay.

Spectrophotometric assays were used to measure succinate cytochrome $c$ reductase, NADH cytochrome $\mathrm{c}$ reductase, NADH dehydrogenase, succinate dehydrogenase, citrate synthase, and cytochrome c oxidase as described previously (33). Reduced cytochrome $\mathrm{c}$ was freshly prepared before each experiment by adding a few grains of sodium hydrosulfite (dithionite) to a $1 \%$ cytochrome c solution in $10 \mathrm{mM} \mathrm{K}$-phosphate buffer, $\mathrm{pH} 7.0$

The activities of $\mathrm{PC}$ and the pyruvate dehydrogenase complex were determined after scraping from the culture plate at the time of assay as described previously $(9,32)$.

Isolation of mitochondria, electrophoresis of mitochondrial proteins, and transfer of proteins to nitrocellulose membrane were performed as described previously (32), except that a $7 \%$ SDS-polyacrylamide gel was used. The membrane was immersed in TBS (20 mM Tris- $\mathrm{HCl}, 500 \mathrm{mM} \mathrm{NaCl}, \mathrm{pH} 7.5)$ for $10 \mathrm{~min}, 3$ $\mathrm{g} / 100 \mathrm{~mL}$ Carnation skim milk powder- $0.5 \mathrm{~g} / 100 \mathrm{~mL}$ gelatin in TBS for $1 \mathrm{~h}, 0.05$ vol\% Tween-20 in TBS twice for $5 \mathrm{~min}$, and subsequently incubated in the presence of a streptavidin-horseradish peroxidase conjugate $(1 / 250$ dilution in $1 \mathrm{~g} / 100 \mathrm{~mL}$ gelatin in TBS) for $2 \mathrm{~h}$. The membrane was washed again twice in Tween-20 in TBS for $5 \mathrm{~min}$ and in TBS also for $5 \mathrm{~min}$. Color was developed by adding $0.1 \mathrm{~g} / 100 \mathrm{~mL}$ diaminobenzidine, 0.1 $\mathrm{g} / 100 \mathrm{~mL}$ imidazole, and $0.015 \% \mathrm{H}_{2} \mathrm{O}_{2}$ in TBS.

Nuclear pellets obtained from $700-\mathrm{g}$ fibroblast homogenates were used for isolation of DNA. The pellets were resuspended in $5 \mathrm{~mL}$ of $100 \mathrm{mM} \mathrm{NaCl}, 50 \mathrm{mM}$ Tris- $\mathrm{HCl}(\mathrm{pH} 8.0), 10 \mathrm{mM}$ EDTA, $200 \mu \mathrm{g} / \mathrm{mL}$ SDS, and $200 \mu \mathrm{g} / \mathrm{mL}$ proteinase $\mathrm{K}$ and placed on a revolving wheel at $37^{\circ} \mathrm{C}$ for $12 \mathrm{~h}$. After phenol extraction, $1 / 10$ vol $3 \mathrm{M} \mathrm{Na}$ acetate $(\mathrm{pH} 5.1)$ and two vol ethanol were added, and DNA was spooled out and resuspended in 1 $\mathrm{mL}$ of $10 \mathrm{mM}$ Tris- $\mathrm{HCl}(\mathrm{pH} \mathrm{8.0)}$ ) and $1 \mathrm{mM}$ EDTA.

Genomic DNA $(10 \mu \mathrm{g})$ was digested with $3 \mathrm{U} / \mu \mathrm{g}$ of restriction endonucleases ( $H$ indIII, EcoRI, $B g l \mathrm{II}$, and $B a m \mathrm{HI}$ ) at $37^{\circ} \mathrm{C}$ for $4 \mathrm{~h}$. The DNA was subjected to electrophoresis in $1 \%$ agarose and transferred to nitrocellulose (34). Before transfer, the gel was denatured with $0.25 \mathrm{M} \mathrm{HCl}$ for $15 \mathrm{~min}$ and $0.5 \mathrm{M} \mathrm{NaOH} / 1.5$ $\mathrm{M} \mathrm{NaCl}$ for $30 \mathrm{~min}$ and neutralized with $0.5 \mathrm{M}$ Tris- $\mathrm{HCl} / 1.5$
$\mathrm{NaCl}(\mathrm{pH} \mathrm{7.0-7.5)}$ for $30 \mathrm{~min}$. Transfer proceeded for $20 \mathrm{~h}$. The filter was heated at $80^{\circ} \mathrm{C}$ for $2 \mathrm{~h}$ in vacuo. Prehybridization was carried out in a solution containing $40 \%$ formamide, $0.6 \mathrm{M}$ sodium chloride and $0.06 \mathrm{M}$ sodium citrate $(4 \times \mathrm{SSC}), 5 \times$ Denhardt's solution, $0.5 \mathrm{mg} / \mathrm{mL}$ denatured salmon sperm DNA, $0.2 \% \mathrm{SDS}$, and $0.1 \mathrm{M}$ Tris- $\mathrm{HCl}(\mathrm{pH} 7.4)$ at $42^{\circ} \mathrm{C}$ for $6 \mathrm{~h}$. The filter was then hybridized overnight at $42^{\circ} \mathrm{C}$ in $40 \%$ formamide, $4 \times \mathrm{SSC}, 1 \times$ Denhardt's, $0.1 \mathrm{M}$ Tris- $\mathrm{HCl}(\mathrm{pH} 7.4), 2.5 \mathrm{~g} / 100$ $\mathrm{mL}$ dextran sulfate, and $10^{6} \mathrm{cpm} /$ lane of ${ }^{32} \mathrm{P}$-labeled $\mathrm{PC}$ probe prepared from denatured double-stranded cDNA using the random priming method. The filter was washed in $4 \times$ SSC, $0.1 \%$ SDS, then in $2 \times \mathrm{SSC}, 0.1 \% \mathrm{SDS}$, and in $0.2 \times \mathrm{SSC}, 0.1 \% \mathrm{SDS}$ (at room temperature for $15 \mathrm{~min}$ ). The filter was blot-dried and hybridization signals were visualized by autoradiography using a Dupont Cronex Lightning Intensifying screen. Protein was determined by the Lowry method (35). A cDNA probe, $1.1 \mathrm{kbp}$ in length, corresponding to the $3^{\prime}$ terminal of PC mRNA was a generous gift of Svend Freytag (University of Michigan Medical School, Ann Arbor, MI) (6).

\section{RESULTS}

Mitochondrial enzyme activities measured in cultured skin fibroblast homogenates of our patient and controls are shown in Table 1. PC residual activity in the patient's cells was only $1.8 \%$ of the control cell activity. The activities of other mitochondrial enzymes were normal.

The electrophoretic profile of biotin-containing mitochondrial proteins is shown in Figure 1. Three discernible bands were visualized in the control cells and PC-deficient cell lines. The band with the highest MW represents the biotin-containing subunit of PC (MW $=125 \mathrm{kD})$; the doublet corresponds to the $\alpha$-subunits of $\beta$-methyl-crotonyl CoA carboxylase (MW $=75$ $\mathrm{kD})$ and propionyl $\mathrm{CoA}$ carboxylase $(\mathrm{MW}=73 \mathrm{kD})$. All cell lines, including our patient's, showed the same pattern. There were no differences in abundance or mobility of the PC subunits between different cell lines.

The cleavage pattern of the digested genomic DNA extracted from fibroblasts of our patient, three other PC-deficient patients with the North American phenotype, and control samples were identical (data not shown).

\section{DISCUSSION}

Two types of PC deficiency have been described in the literature. The French phenotype presents in the neonatal period and is characterized clinically by anorexia, weak cry, convulsions, stupor, hyporeactivity, hypotonia, abnormal respiratory pattern, subsequent hypertonia, extrapyramidal tract signs, and severely retarded mental and motor development. Biochemical charac-

Table 1. Cultured skin fibroblast enzyme activities*

\begin{tabular}{lcc}
\hline \multicolumn{1}{c}{ Enzyme } & Patient $\dagger$ & $\begin{array}{c}\text { Controls } \\
\text { (mean } \pm \text { SD) } \ddagger\end{array}$ \\
\hline Pyruvate carboxylase & 0.03 & $1.62 \pm 0.39$ \\
Pyruvate dehydrogenase complex & 1.86 & $1.72 \pm 0.35$ \\
Cytochrome c oxidase & 37.7 & $50.3 \pm 11.6$ \\
NADH dehydrogenase & 633 & $910 \pm 169$ \\
NADH cytochrome c reductase (to- & 190 & $210 \pm 30$ \\
$\quad$ tal) & 11.6 & $16.7 \pm 4.6$ \\
Succinate cytochrome c reductase & 9.43 & $12.3 \pm 3.2$ \\
Succinate dehydrogenase & 32.8 & $76.3 \pm 15.1$ \\
Citrate synthase &
\end{tabular}

${ }^{*} \mathrm{~nm} \cdot \mathrm{min}^{-1} \cdot \mathrm{mg}_{\text {protein }}{ }^{-1}$ activities represent: for pyruvate carboxylase, $\mathrm{nmol} \mathrm{HCO}_{3}$ fixed; for pyruvate dehydrogenase, complex $\mathrm{nmol} \mathrm{CO}_{2}$ produced; for citrate synthase, nmol CoASH produced; and for other enzymes, nmol substrate oxidized.

$\dagger$ Enzyme activity represents the average value of two assays.

$\$$ Pyruvate carboxylase: $n=113$; pyruvate dehydrogenase: $n=112$; other assays: $n=41$. 


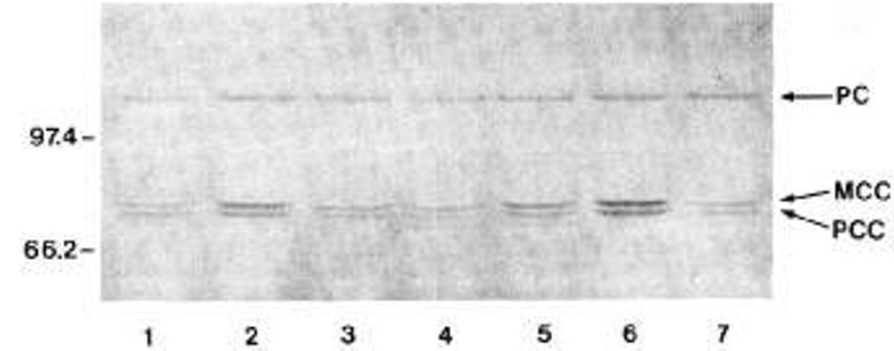

Fig. 1. Mitochondria were isolated from cultured skin fibroblasts and electrophoresed on SDS-7\% polyacrylamide gel. The proteins were transferred to nitrocellulose membrane and labeled with streptavidin-peroxidase (see Materials and Methods for detail). MW markers (kD) are shown in the left margin. Lanes 1 and 7 are control samples; lane 2 is the patient with the benign $\mathrm{PC}$ variant; and lanes 3-6 are patients with the classic forms of fatal PC deficiency. Normal abundance of CRM for PC and for the $\alpha$-subunits of $\beta$-methylcrotonyl CoA carboxylase $(M C C)$ and propionyl $\mathrm{CoA}$ carboxylase $(P C C)$ is present in all seven lanes.

teristics include lactic acidosis, increased lactate/pyruvate ratio, citrullinemia, hyperlysinemia, hyperammonemia, and ketosis. Most of these patients died within the first 4 mo of life. Patients with the North American type become symptomatic between 2 and $5 \mathrm{mo}$ of age, associated with delayed mental and motor development, failure to thrive, apathy, hypotonia, pyramidal tract signs, ataxia, nystagmus, and convulsions. Episodes of acute vomiting, tachypnea, and acidosis characteristically are precipitated by metabolic or infectious stress. Serum lactate and pyruvate values usually are less increased in the North American type.

Patients of both types suffer from severe mental and motor retardation and most die in infancy. Robinson et al. (18) described two cases, initially symptomatic at 2 and $5 \mathrm{mo}$, respectively, who survived until 5 y of age. One of the patients described by Tada et al. (29) was 7\%/12 y old when he died. Our patient was normal until 7 mo of age, but subsequently developed several acute episodes of anorexia, vomiting, tachypnea, tachycardia, and ataxia. She had metabolic acidosis and increased serum lactate, pyruvate, $\beta$-hydroxybutyrate, acetoacetate, alanine, lysine, and proline; the aspartate value was undetectably low. She was PC-deficient as shown by the decreased catalytic activity in her cultured skin fibroblasts (Table 1). The metabolic profile is similar to previously reported PC-deficient patients with the North American phenotype, but clinically she has continued to show normal motor and mental development.

More than half of the patients with the French phenotype had absence of PC protein and the corresponding mRNA. Patients with the North American phenotype generally have CRM (CRMpositive) $(11,18)$. Our patient is CRM-positive (Fig. 1), as expected by the onset of symptoms in early infancy.

PC serves an important role in cell metabolism. First, it serves an anaplerotic function replenishing the Krebs cycle intermediates and, second, it serves a role in gluconeogenesis. In general, it is believed that the lost anaplerotic function is more relevant to the metabolic crises experienced by these patients. This impression is evidenced by the low aspartic acid concentrations in these patients, inasmuch as this amino acid is in equilibrium with oxaloacetate. Aspartic acid insufficiency is particularly severe in the French phenotype and is responsible for the citrullinemia and hyperammonemia. Aspartic acid supplementation may mitigate some of these systemic metabolic disturbances (36).

The rather benign course of PC deficiency in our patient remains unexplained. Tissue heterogeneity would provide a convenient explanation for this patient's condition. However, Atkin et al. $(7,8)$ measured PC activity in liver, kidney, brain, cultured skin fibroblasts, and white blood cells of one patient and found it to be deficient in all tissues, suggesting that only one molecular form of PC exists in human tissues. Animal studies also confirm this observation (10). These observations are compatible with the known fact that PC is a tetramer containing four identical subunits. To invoke tissue heterogeneity as the mechanism accounting for the benign clinical state, we would need to propose that PC exists in different isoforms in the affected and unaffected tissues. Differential splicing of mRNA transcripts in these diverse tissues would represent one possible explanation.

Synthesis of an alternative metabolic intermediate, particularly in the brain, to replenish the Krebs cycle intermediates might explain the benign course. One possibility is that the brain enzymes constituting the "glutamine loop" could produce more $\alpha$-ketoglutarate from glutamine to compensate for the decreased oxaloacetate formation (27). This metabolic adaptation probably happens in PC-deficient patients, as witnessed by the decreased glutamine in autopsied brain of one patient and in cerebrospinal fluid and plasma of four living patients with PC deficiency (27). Why this metabolic adaptation would be more efficient in our patient and less effective in the other reported cases cannot be answered.

It also remains theoretically possible that a fetal PC isoform persists during early infancy and protects the developing organs, including the brain. However, we have no evidence to support this hypothesis. In fact, Robinson et al. (17) have shown evidence for brain involvement during fetal development in a PC-deficient patient.

The enzyme activity measured in vitro may not be a true reflection of the enzyme activity in vivo. However, the intermittent metabolic crises and the blood and urine metabolite profiles are entirely compatible with PC deficiency. Of interest in this regard is the fact that the patient never suffered any hypoglycemic episodes. In fact, when she presented at $14 \mathrm{mo}$, the blood glucose concentration was elevated and she was treated with one dose of insulin. This metabolic disturbance is distinctly unusual in patients with PC deficiency. Although we have no explanation for the patient's hyperglycemia during the metabolic crises, it is again intriguing to speculate about the possible existence of tissue-specific isoforms, but available data militate against this speculation.

At this point we can only report that our patient has a CRMpositive PC deficiency, but, for reasons that remain obscure, her clinical course has been rather benign and her psychomotor functioning at $7 \mathrm{y}$ of age is essentially normal.

Acknowledgments. The authors thank Pamela Pulver for tissue culture assistance, Ann Zaragoza for secretarial assistance, and Wilma L. Krause, M.D. for her initial medical care.

\section{REFERENCES}

1. Keech DB, Utter MF 1963 Pyruvate carboxylase II: properties. J Biol Chem $238: 2609-2614$

2. Scrutton MC, White MD 1974 Purification and properties of human liver pyruvate carboxylase. Biochem Med 9:271-292

3. Utter MF, Keech DB 1963 Pyruvate carboxylase I: nature of the reaction. J Biol Chem 238:2603-2608

4. Barrit GJ, Zander GL, Utter MF 1976 The regulation of pyruvate carboxylase activity in gluconeogenic tissues. In: Hanson RW, Mehlman MA (eds) Gluconeogenesis: Its Regulation in Mammalian Species. John Wiley, New York, p 3

5. Ballard FJ, Hanson RW, Reshef L 1970 Immunochemical studies with soluble and mitochondrial carboxylase activities from rat tissues. Biochem J 119:735-742

6. Freytag SO, Collier JH 1984 Molecular cloning of a cDNA for human pyruvate carboxylase. J Biol Chem 259:12831-12837

7. Atkin BM, Buist NRM, Utter MF, Leiter AB, Banker BQ 1979 Pyruvate carboxylase deficiency and lactic acidosis in a retarded child without Leigh's disease. Pediatr Res 13:109-116

8. Atkin BM, Utter MF, Weinberg MB 1979 Pyruvate carboxylase and phosphoenolpyruvate carboxykinase activity in leucocytes and fibroblasts from a patient with pyruvate carboxylase deficiency. Pediatr Res 13:38-43

9. De Vivo DC, Haymond MW, Leckie MP, Bussmann YL, McDougal Jr DB Pagliara AS 1977 The clinical and biochemical implications of pyruvate carboxylase deficiency. J Clin Endocrinol Metab 45:1281-1296

10. Barden RE, Taylor BL, Isohashi F, Frey II WH, Zander G, Lee JC, Utter MF 1975 Structural properties of pyruvate carboxylase from chicken liver and other sources. Proc Natl Acad Sci USA 72:4308-4312 
11. Robinson BH, Oei J, Saudubray JM, Marsac C, Bartlett K, Quan F, Gravel R 1987 The French and North American phenotypes of pyruvate carboxylase deficiency. Correlation with biotin-containing protein by ${ }^{3} \mathrm{H}$-biotin incorporation, ${ }^{35} \mathrm{~S}$-streptavidin labeling, and northern blotting with a cloned cDNA probe. Am J Hum Genet 40:50-59

12. Bartlett K, Ghneim HK, Stirk JH, Dale G, Alberti KGMM 1984 Pyruvate carboxylase deficiency. J Inherited Metab Dis (suppl)7:74-78

13. Coude FX, Ogier H, Marsac C, Munnich A, Charpentier C, Saudubray JM 1981 Secondary citrullinemia with hyperammonemia in four neonatal cases of pyruvate carboxylase deficiency. Pediatrics 68:914

14. Greter J, Gustafsson J, Holme E 1985 Pyruvate carboxylase deficiency with urea cycle impairment. Acta Paediatr Scand 74:982-986

15. Merinero Cortes B, Del Valle Martinez J, Perez-Cerda Silvestre C, Garcia Munoz MJ, Cortes Coto MT, Garcia Aparicio J, Saez Perez E, Ugarte Perez M 1988 Acidosis lactica neonatal debida a deficiencia aislada de piruvato carboxilasa. An Esp Pediatr 29:57-60

16. Pollock MA, Cumberbatch M, Bennet MJ, Gray RGF, Brand M, Hyland K, Congdon PJ, Pitts-Tucker T, Gray S 1986 Pyruvate carboxylase deficiency in twins. J Inherited Metab Dis 9:29-30

17. Robinson BH, Toone J, Petrova-Benedict R, Dimmick JE, Oei J, Applegarth DA 1985 Prenatal diagnosis of pyruvate carboxylase deficiency. Prenat Diagn 5:67-71

18. Robinson BH, Oel J, Sherwood WG, Applegarth D, Wong L, Haworth J, Goodyer P, Casey R, Zaleski LA 1984 The molecular basis for the two different clinical presentations of classical pyruvate carboxylase deficiency. Am J Hum Genet 36:283-294

19. Rutledge SL, Snead OC, Kelly DR, Kerr DS, Swann JW, Spink DL, Martin DL 1989 Pyruvate carboxylase deficiency: acute exacerbation after ACTH treatment of infantile spasms. Pediatr Neurol 5:249-252

20. Saudubray JM, Marsac C, Charpentier C, Cathelineau C, Besson-Leaud M, Leroux JP 1976 Neonatal congenital lactic acidosis with pyruvate carboxylase deficiency in two siblings. Acta Paediatr Scand 65:717-724

21. Vidailhet M, Lebebvre E, Beley G, Marsac C 1981 Neonatal lactic acidosis with pyruvate carboxylase inactivity. J Inherited Metab Dis 4:131-132

22. Wong LT, Davidson AG, Applegarth DA, Dimmick JE, Norman MG, Toone JR, Pirie G, Wong J 1986 Biochemical and histologic pathology in an infant with cross-reacting material (negative) pyruvate carboxylase deficiency. Pediatr Res 20:274-279

23. Brunette MG, Delvin E, Hazel B, Scriver CR 1972 Thiamine responsive lactic acidosis in a patient with deficient low Km pyruvate carboxylase activity in liver. Pediatrics 50:702-711

24. Haworth JC, Robinson BH, Perry TL 1981 Lactic acidosis due to pyruvate carboxylase deficiency. J Inherited Metab Dis 4:57-58

25. Maesaka H, Komiya K, Misugi K, Tada K 1976 Hyperalaninemia, hyperpyruvicemia and lactic acidosis due to pyruvate carboxylase deficiency of the liver; treatment with thiamine and lipoic acid. Eur J Pediatr 122:159-168

26. Oizumi J, Shaw KNF, Giudici TA, Carter M, Donnell GN, Ng WG 1983 Neonatal pyruvate carboxylase deficiency with renal tubular acidosis and cystinuria. J Inherited Metab Dis 6:89-93

27. Perry TL, Haworth JC, Robinson BH 1985 Brain amino acid abnormalities in pyruvate carboxylase deficiency. J Inherited Metab Dis 8:63-66

28. Robinson BH, Taylor J, Sherwood WG 1980 The genetic heterogeneity of lactic acidosis: occurrence of recognizable inborn errors of metabolism in a pediatric population with lactic acidosis. Pediatr Res 14:956-962

29. Tada K, Takada G, Omura K, Itokawa Y 1978 Congenital lactic acidosis due to pyruvate carboxylase deficiency: absence of an inhibitor of TPP-ATP phosphoryl transferase. Eur J Pediatr 127:141-147

30. Tsuchiyama A, Oyanagi K, Hirano S, Tachi N, Sogawa H, Wagatsuma K, Nakao T, Isugawa S, Kawamura Y 1983 A case of pyruvate carboxylase deficiency with later prenatal diagnosis of an unaffected sibling. J Inherited Metab Dis 6:85-88

31. Van Biervliet JPGM, Bruinvis L, van der Heiden C, Ketting D, Wadman SK, Willemse JL, Monnens LAH 1977 Report of a patient with severe, chronic lactic acidaemia and pyruvate carboxylase deficiency. Dev Med Child Neurol 19:392-401

32. Old SE, De Vivo DC 1989 Pyruvate dehydrogenase complex deficiency: biochemical and immunoblot analysis of cultured skin fibroblasts. Ann Neurol 26:746-751

33. DiMauro S, Servidei S, Zeviani M, DiRocco M, De Vivo DC, DiDonato S, Uziel G, Berry K, Hoganson G, Johnsoen SD, Johnson PC 1987 Cytochrome c oxidase deficiency in Leigh syndrome. Ann Neurol 22:498-506

34. Southern EM 1975 Detection of specific sequences among DNA fragments separated by gel electrophoresis. J Mol Biol 98:503-517

35. Lowry OH, Rosenbrough NJ, Farr AL, Randall RJ 1951 Protein measurement with the folin phenol reagent. J Biol Chem 193:265-275

36. Baal MG, Gabreels FJ, Renier WO, Hommes FA, Gijsbers Th HJ, Lamers KJB, Kok JCN 1981 A patient with pyruvate carboxylase deficiency in the liver: treatment with aspartic acid and thiamine. Dev Med Child Neurol 23:521-530 